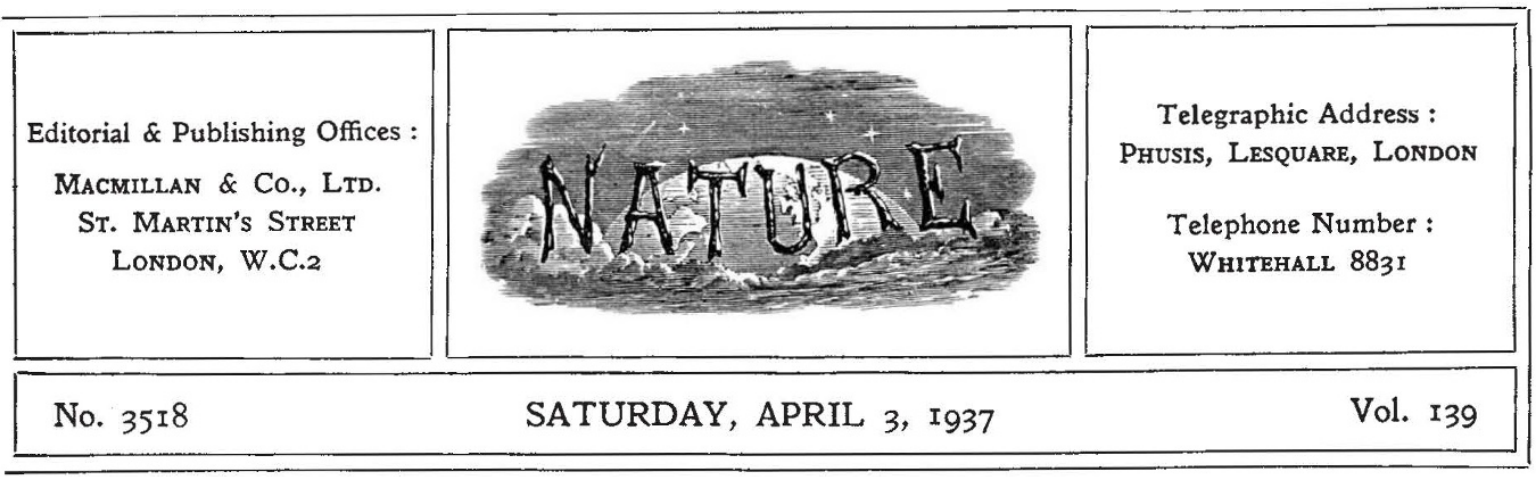

\title{
British Engineers Abroad and their Prospects
}

$\mathrm{I}^{\mathrm{N}}$ the past, an important source of British influence and prestige has been the large number of British engineers occupying responsible positions in all parts of the world. One serious result of the many changes in world conditions since the Great War is that the position of the British engineer abroad is no longer what it was. The development of technical education in the Dominions and in India now enables these countries to dispense almost entirely with engineers from Great Britain to undertake ordinary engineering work, and from similar and other causes, including nationalistic pride, the openings in the United States, South America, Egypt and other States have been very greatly restricted. Young Argentine engineers, educated in Europe, now occupy responsible positions in their own country, which is developing very rapidly on the industrial side. In the Argentine, also, no engineer is allowed to practise on his own account unless he has graduated in, or has had his foreign qualifications revalidated by, an Argentine university : for this a very high fee is charged.

The national importance of this subject, and particularly its direct relationship to the lives and prospects of the young engineer, using the word in the widest possible sense to include technically trained men of all kinds, has caused the old Centralians to discuss it in general meeting under the chairmanship of Sir Alfred Chatterton, who has himself had a long and distinguished career in India. The Old Centralians are the Old Students' Association of what is now the City and Guilds Engineering College, London; they include many of the older generation in their ranks who are well qualified to give reliable evidence on the problem. The "Central" has now sent forth young engineers for more than fifty years: the first small batch included Sir Alfred Chatterton and Herbert A. Humphrey. At times more than half the students went overseas on graduation; to-day very few are able to find work abroad.

There are still openings abroad for men of special experience who are required for specific work, but such normally involve only short-time engagements; even in these there is increasing competition from American and Continental engineers. It is urged that in the future only first-class men would be wanted abroad and then for comparatively short periods; the country which has the best engineering representation, whether on the professional or commercial side, will in the long run obtain the most foreign work.

Trade is said to follow the flag. The engineer carries the flag or even marches ahead of it; he tends to buy the large quantity of material required for his projects in his native country. Hence it will be appreciated that his replacement will react adversely upon our industries.

The average Englishman to-day is strangely reluctant to go abroad; the comforts of city life at home appeal more than the idea of roughing it. There is no particular indication that the engineering schools and technical institutes are turning out more men than the industrial life of Great Britain can absorb ; indeed, at the moment when the nation is re-arming and its workshops are being largely rebuilt and reorganized, there is more than enough work. Another difficulty is the apparent prejudice against men who have returned from abroad, who often find it difficult to make a fresh start on their return. The discussion made clear that for appointments abroad there is a scarcity of men for the better positions-of 
all-round men possessing all the qualities which are necessary for success in the Colonies.

The immediate problem to be solved is how to prevent a period of overseas service, causing as it does a serious break in the home career, from injuring the future prospects of a technical man. Obviously no general solution is possible: the first practicable step suggested by the Old Centralians is to form an Overseas Engineers Association, which would enjoy the active support of all home professional bodies representative of engineers and engineering colleges as well as of old students' associations, consulting engineers, contracting firms and large engineering and industrial firms. Such an organization would keep a record of engineers qualified to carry out work abroad. It would constitute a source from which contributing organizations would draw engineering staff when need arose and make it easier for the employers to obtain fully trained and qualified men.

The problem is to some extent associated with the training of the engineer, and the time may be opportune to re-examine the engineering courses in relation to modern requirements. The young American engineer, for example, is more highly favoured on outdoor work by overseas employers; it may be that his training, though less theoretical, none the less fits him better for his work. Mining engineering is known to have this aspect of its teaching under consideration.

It is widely held that the present three-year undergraduate course in engineering in British universities and technical colleges should be ex. tended to four years, not so much with a more extensive curriculum, but designed rather that the students should be given more time to think over their work and to read for themselves.

Looking at the question broadly, it would appear to have two aspects : one is that of giving Englishmen a chance to go abroad without injuring their prospects on their return, which is largely a question of organization and is possible of solution on lines such as the Old Centralians visualize. The more important aspect, however, is the technical equipment of the Englishman so as to enable him to hold his own in a competitive nationalistic world. Besides personality and character and professional knowledge, he must have ideas and originality. These can be trained out of a student more easily than developed in him.

\section{The Trend of Population in Great Britain}

$\mathrm{T}$ HE debate on this subject which took place in the House of Commons on February 10 is one of the many signs of the increasing interest which is being felt in Great Britain in population questions. Mr. J. R. H. Cartland, who moved the resolution, expressed the view, which was accepted by the House, that "the tendency of the population to decline may well constitute a danger to the maintenance of the British Empire and to the economic well-being of the nation"; and the Government was requested to institute an inquiry into the problem. No new facts were brought forward during the debate, which proceeded on what may be called orthodox lines. Attention was directed to the gradual diminution of the birth-rate since 1875 ; to the resulting fall in the net reproduction rate; and to the ageing of our population. The question of birth-control was touched upon, and also the present general tendency of married couples to have small families. Mr. Cartland mentioned the existence of the unofficial Population Investigation Committee, which has been formed at the instance of the Eugenics Society.

Mr. Cartland quoted the important pronouncement of the Chancellor of the Exchequer when he introduced the budget on April 15, 1935: "I must say that I look upon the continued diminution of the birth-rate in this country with considerable apprehension. At the present time it may seem that we have here a larger population than we are-able to support in England. . . . But I have a feeling that the time may not be far distant ... when the countries of the British Empire will be crying out for more citizens of the right breed and when we in this country shall not be able to supply the demand."

Mr. D. Sandys, who seconded the motion, directed attention to the rapid increase in the populations of Russia and Japan. He recalled the estimate of Dr. Enid Charles to the effect that, in sixty years' time, 64 per cent of the women in Great Britain may be past the child-bearing age. He indicated the possibility that, for want of British 